\title{
GERMINATION POTENTIAL OF TODDY PALM (CARYOTA URENS), CARDAMOM (ELETTARIA CARDAMOMUM) AND NUTMEG (MYRISTICA FRAGRANS) SEEDS UNDER IN VIVO CONDITIONS
}

\author{
Rodrigo WDRJ, Dahanayake Nilanthi* and Senanayake SGJN \\ Department of Agricultural Biology, Faculty of Agriculture, University of Ruhuna, Mapalana, Kamburupitiya, \\ Sri Lanka
}

Accepted: 4 June 2012

\section{Abstract}

Kithul (Caryota urens: Arecaceae), Cardamom (Elettaria cardamomum: Zingiberaceae) and Nutmeg (Myristica fragrans: Myristaceae) are three species having great export potential in Sri Lanka. Due to the hard seed coat the germination potential of these species are low. Therefore a study was undertaken to explore possibilities of improving the seed germination through mechanical, physical and chemical treatments and to develop a cost effective and rapid seed germination method. $C$. urens seeds when treated with $50 \% \mathrm{HNO}_{3}$ for 5 minutes recorded the highest germination $(85 \%)$ followed by $30 \% \mathrm{HNO}_{3}$ for $5 \mathrm{~min}$. (77.5\%) and tepid water for $24 \mathrm{~h}(\mathbf{7 5 \%})$ as compared to untreated control $(\mathbf{1 0 \%})$ and other treatments. Seeds of $E$. cardamomum treated with $50 \% \mathrm{H}_{2} \mathrm{SO}_{4}$ for $5 \mathrm{~min}$ recorded the highest germination $(65 \%)$ followed by $75 \% \mathrm{HNO}_{3}$ for $10 \mathrm{~min}(55 \%)$ and $75 \% \mathrm{HNO}_{3}$ for $15 \mathrm{~min}(45 \%)$. Nutmeg seeds treated with $0.5 \% \mathrm{KNO}_{3}$ for $30 \mathrm{~min}$. showed improved germination. The results obtained in this study will be useful for plant breeders and farmers who cultivate these species commercially.

Key words: Caryota urens, Elettaria cardamomum, Myristica fragrans, Seed germination, in-vivo condition

\section{INTRODUCTION}

Toddy palm or Kithul (in Sinhala) (Caryota urens: Arecaceae), a popular multipurpose palm among the rural communities, is also gaining importance in floriculture industry. In Sri Lanka the sap extracted from inflorescence of Kithul is used to produce treacle, jaggery, toddy and vinegar and the palm pith is used to extract special flour and the stem is used as fiber timber. The long duration (about 4 months) taken for seed germination is considered as one of the major issues in the propagation of this species (Department of Export Agriculture 1995).

Cardamom (Elettaria cardamomum) is known as 'Queen of Spices'. At present the production is sufficient to meet the world demand. Cardamom is propagated through suckers or seedlings however the latter method is preferred as it helps to control the spread of the virus dis- ease 'katte' (Condiments and Spices 2011). Its seeds have prolonged dormancy due to the hard seed coat (Radhamani et al. 1991). Cardamom is an expensive spice, seeds have a pleasant aroma and slightly pungent taste. Essential oil extracted from the seeds is used to flavor processed foods, in perfumery, liqueurs and other beverages. In Sri Lanka total extent under Cardamom is about 2,794ha and the total annual production of cardamom is $61 \mathrm{t}$ (Department of Export Agriculture 2009).

Nutmeg and mace are two main products of the plant that are used to extract essential oils. Antioxidants properties of nutmeg are well documented (Madsen and Bertelsen 1996, Lagouri and Boskou 1995). It is an important tree spice in the world and major problem related to nutmeg is the loss of seed viability soon after harvest (Sangakkara 1993 and Gunasekaran 2000). 


\section{RODRIGO ET AL GERMINATION POTENTIAL OF TODDY PALM, NUTMEG AND CARDAMOM}

With increasing consumer demand for quality planting material of these species, it has become necessary to conduct research to identify low cost and easy to follow methods to increase the germination potential of seeds. Therefore this research was undertaken to study the influence of different treatment methods to identify cost effective technique to enhance the germination potential of seeds of these three crops; namely Kithul (C. urens: Arecaceae), Cardamom (E. cardamomum: Zingiberaceae and Nutmeg ( $M$. fragrans: Myristaceae).

\section{MATERIALS AND METHODS}

Experiment was carried out at the Faculty of Agriculture, University of Ruhuna, Sri Lanka. Fully ripened fresh fruits of Kithul ( $C$. urens: Arecaceae), Cardamom (E. cardamomum: Zingiberaceae) and Nutmeg ( $M$. fragrans: Myristaceae) were collected from the field. The pericarps of collected seeds were carefully removed and washed thoroughly to remove mucilage around the seeds. The uniform seeds were selected for different treatments (Table 1) from the collected and processed seed lots.

Seeds of $C$. urens, E. cardamomum and $M$. fragrans were subjected to 38,40 and 14 different seed treatments respectively. Treated seeds were thoroughly washed three times with distilled water and planted in trays. Treatments were replicated four times and each replicate of Kithul and cardamom included 20 seeds. Each replicate of nutmeg had 10 seeds. The number of germinated seeds in each treatment was recorded separately in weekly interval. Then germination percentage in each treatment was calculated. Analysis of Variance was done at the 0.05 significant levels by using SAS package (v6.12) and mean separation was done by using Duncan's New Multiple Range Test (DMRT).

\section{RESULTS AND DISCUSSION}

C. urens: Seeds of C. urens treated with $50 \%$ $\mathrm{HNO}_{3}$ for 5 minutes $\left(\mathrm{T}_{5}\right)$ showed the highest germination $(85 \%)$ within a 2 -weeks (Figure
1). The germination percentage of seeds treated with $30 \% \mathrm{HNO}_{3}$ for $5 \mathrm{~min}$. ( $\left.\mathrm{T}_{27}\right)$ observed to be $77 \%$ but it took longer period to initiate the seed germination compared to $\mathrm{T}_{5}$. Seeds soaked with tepid water for $24 \mathrm{~h}\left(\mathrm{~T}_{21}\right)$ started to germinate from third week after washing showing $75 \%$ germination percentage. Control $\left(\mathrm{T}_{1}\right)$ initiate seed germination during fourth week $(7.5 \%)$ and showed $10 \%$ germination in 5-8 weeks.

Copeland and McDonald (1995) reported that mechanical treatments were the best for breaking seed coat dormancy. However, according to the present study chemical treatments were the best for breaking seed coat dormancy. Some physical methods like seeds soaking in tepid water also found to be good for breaking seed coat dormancy. According to Saroshini (2006) removal of small portion of endosperm was the best method and gave 53\% germination after eleven weeks. According to the present study the same treatment gave only $40 \%$ germination after eight weeks. In the present study mechanical methods showed low seed germination percentages compared to chemical and physical methods. This happened perhaps due to mechanical methods caused damaged to the embryo and reduced seed germination. Some treatments not showed even one seed germinated due to high temperature and high concentrations of chemicals caused death of embryos.

E. cardamomum: The germination percentage of E. cardamomum seeds treated with $50 \%$ $\mathrm{H}_{2} \mathrm{SO}_{4}$ for 5, 10 and 15 min. recorded respectively as $60 \%, 55 \%$ and $45 \%$ (Figure 2). Furthermore seeds treated with $25 \% \mathrm{H}_{2} \mathrm{SO}_{4}$ for 5 minutes $\left(\mathrm{T}_{21}\right)$ and $50 \% \mathrm{HNO}_{3}$ for 5 minutes $\left(\mathrm{T}_{5}\right)$ showed $40 \%$ and $25 \%$ germination percentages respectively. Seeds treated with $75 \%$ $\mathrm{HNO}_{3}$ for 10 min. showed a higher germination percentage $(55 \%)$ within a short period of 6 weeks as compared to other treatments. Control $\left(\mathrm{T}_{1}\right)$ initiated seed germination during eighth week and showed only $20 \%$ germination after 10 weeks. The present study showed chemical treatments are the best for breaking seed coat 
Tropieal Agrieultural Pesearch \& Extension 15(4): 2012

Table 1: Different treatments tested to improve the seed germination of Caryota urens, Elettaria cardamomum and Myristica fragrans

\begin{tabular}{|c|c|c|}
\hline & Treatment & Assigned treatment No \\
\hline Control & No treatment & $\mathrm{T}_{1}$ \\
\hline \multirow[t]{13}{*}{ Chemical } & $75 \% \mathrm{HNO}_{3}(5,10,15 \mathrm{~min})$ & $\mathrm{T}_{2}, \mathrm{~T}_{3}, \mathrm{~T}_{4}$ \\
\hline & $50 \% \mathrm{HNO}_{3}(5,10,15 \mathrm{~min})$ & $\mathrm{T}_{5}, \mathrm{~T}_{6}, \mathrm{~T}_{7}$ \\
\hline & $25 \% \mathrm{HNO}_{3}(5,10,15 \mathrm{~min})$ & $\mathrm{T}_{8}, \mathrm{~T}_{9}, \mathrm{~T}_{10}$ \\
\hline & $75 \% \mathrm{CH}_{3} \mathrm{COOH}(5,10 \mathrm{~min})$ & $\mathrm{T}_{11}, \mathrm{~T}_{12}$ \\
\hline & $50 \% \mathrm{CH}_{3} \mathrm{COOH}(5,10 \mathrm{~min})$ & $\mathrm{T}_{13}, \mathrm{~T}_{14}$ \\
\hline & $25 \% \mathrm{CH}_{3} \mathrm{COOH}(5,10 \mathrm{~min})$ & $\mathrm{T}_{15}, \mathrm{~T}_{16}$ \\
\hline & $50 \% \mathrm{HCl}(5,10 \mathrm{~min})$ & $\mathrm{T}_{17}, \mathrm{~T}_{18}$ \\
\hline & $25 \% \mathrm{HCl}(5,10 \mathrm{~min})$ & $\mathrm{T}_{19}, \mathrm{~T}_{20}$ \\
\hline & $25 \% \mathrm{H}_{2} \mathrm{SO}_{4}(5,10 \mathrm{~min})$ & $\mathrm{T}_{21}, \mathrm{~T}_{22}$ \\
\hline & $50 \% \mathrm{H}_{2} \mathrm{SO}_{4}(5,10 \mathrm{~min})$ & $\mathrm{T}_{23}, \mathrm{~T}_{24}$ \\
\hline & $80 \%$ Alcohol $(15,30 \mathrm{~min})$ & $\mathrm{T}_{25}, \mathrm{~T}_{26}$ \\
\hline & $50 \%$ Alcohol $(15,30 \mathrm{~min})$ & $\mathrm{T}_{27}, \mathrm{~T}_{28}$ \\
\hline & Cholorox $10 \% 10 \mathrm{~min}$ & $\mathrm{~T}_{37}$ \\
\hline \multirow[t]{3}{*}{ Mechanical } & Rubbed with coarse sand & $\mathrm{T}_{29}$ \\
\hline & Rubbed with two sand papers & $\mathrm{T}_{31}$ \\
\hline & $\begin{array}{l}\text { Rubbed with sand wash - mix with wood ash - dry } \\
\text { in shade }\end{array}$ & $\mathrm{T}_{39}$ \\
\hline \multirow[t]{4}{*}{ Physical } & Soaking in water $12 \mathrm{~h}$ & $\mathrm{~T}_{30}$ \\
\hline & Dipped in $100^{\circ} \mathrm{C}$ water $1,2,3,4,5 \mathrm{~min}$ & $\mathrm{~T}_{32}, \mathrm{~T}_{33}, \mathrm{~T}_{34}, \mathrm{~T}_{35}, \mathrm{~T}_{36}$ \\
\hline & Hot water $50^{\circ} \mathrm{C}$ for $30 \mathrm{~min}$ & $\mathrm{~T}_{38}$ \\
\hline & Wrapped in wet gauze & $\mathrm{T}_{40}$ \\
\hline
\end{tabular}

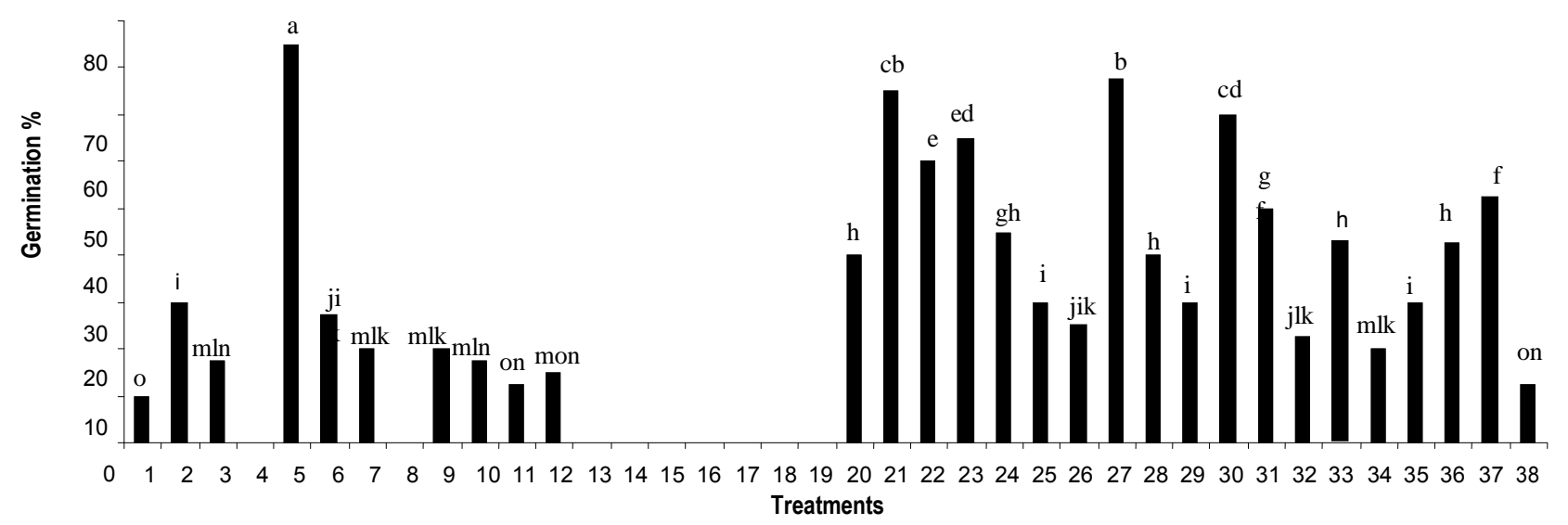

Figure 1. Germination percentage of $C$. urens seeds under different seed treatments within eight weeks. Bars (representing different treatment effects) having same lower case letters are not significantly different at $5 \%$ level in Duncan's Multiple Range Test. 


\section{RODRIGO ET AL GERMINATION POTENTIAL OF TODDY PALM, NUTMEG AND CARDAMOM}

dormancy of E. cardamomum. Although Radhamani et al (1991) has indicated that seeds of E. cardamomum treated with $25 \% \mathrm{H}_{2} \mathrm{SO}_{4}$ for 10 minutes and $80 \%$ alcohol for 30 minutes were the best treatments in breaking seed coat dormancy the present study did not support the above observations. The mechanical methods tested gave the lowest germination percentages compared to chemical methods. This could be due to incomplete removal of hard seed coat or damage caused to the embryo.

M. fragrans: Only the Nutmeg seeds treated with $0.5 \% \mathrm{KNO}_{3}$ for $30 \mathrm{~min}\left(\mathrm{~T}_{6}\right)$ germinated in 6 weeks. All other treatments found not successful in breaking the seed dormancy.

\section{CONCLUSIONS}

Kithul (C. urens), seeds treated with $50 \%$ $\mathrm{HNO}_{3}$ for 5 minutes recorded the highest germination $(85 \%)$. Seeds of Cardamom (E. cardamomum) showed $65 \%$, and $55 \%$ germination when treated with $50 \% \mathrm{H}_{2} \mathrm{SO}_{4}$ for $5 \mathrm{~min}$ and $75 \% \quad \mathrm{HNO}_{3}$ for $10 \mathrm{~min}$ respectively. Among the treatments tested. Only the Nutmeg (M. fragrans) seeds treated with $0.5 \%$ $\mathrm{KNO}_{3}$ for 30 minutes germinated.

\section{REFERENCES}

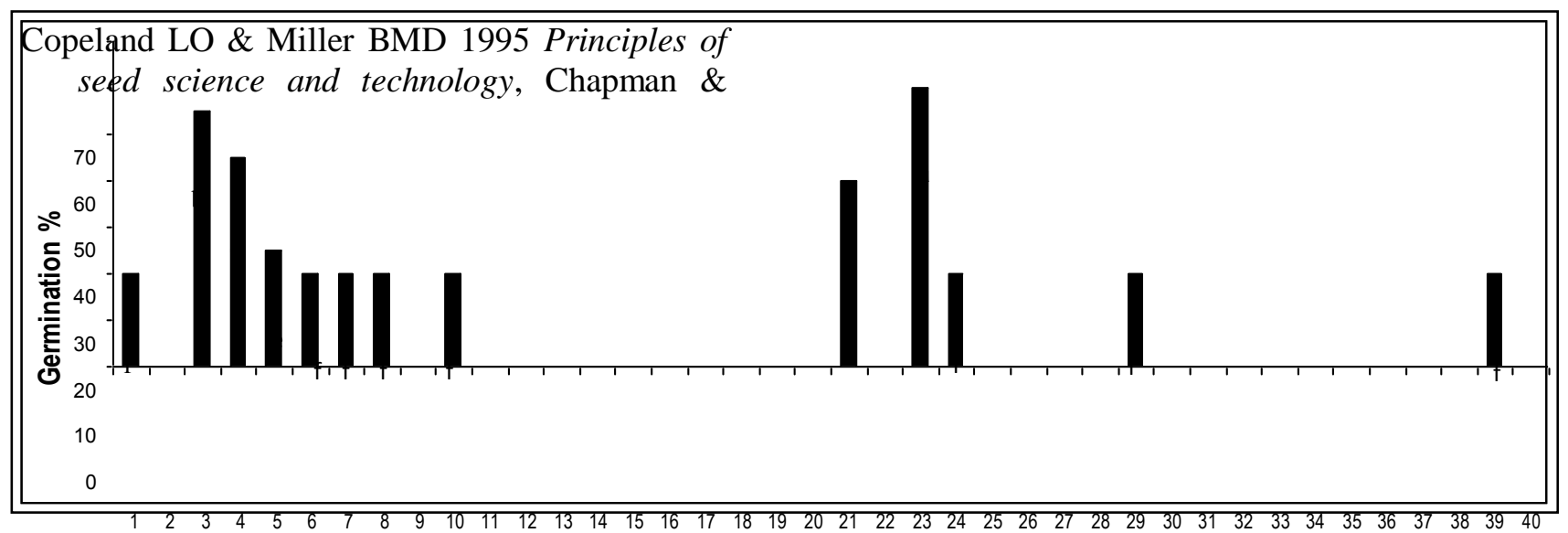

Treatments

Figure 2. Germination percentage of $E$. cardamomum seeds under different seed treatments within ten weeks.Bars (representing different treatment effects) having same lower case letters are not significantly different at $5 \%$ level in Duncan's Multiple Range Test. 